Images in...

\title{
An unusual cause of miliary radiographic pattern
}

\author{
Ahmed Fahim, Mohammad N Khan \\ Department of Respiratory Medicine, Mid Yorkshire Hospitals, Wakefield, UK
}

Correspondence to Dr Ahmed Fahim, ahmedfahim@doctors.org.uk

\section{DESCRIPTION}

A 26-year-old woman presented to our medical assessment unit with a 2 -week history of breathlessness and cough. She was a lifelong non-smoker and had kept a parrot for many years. She was in type 1 respiratory failure with oxygen saturations of $87 \%$ and $\mathrm{PO}_{2}$ of $7.8 \mathrm{kpa}$ breathing

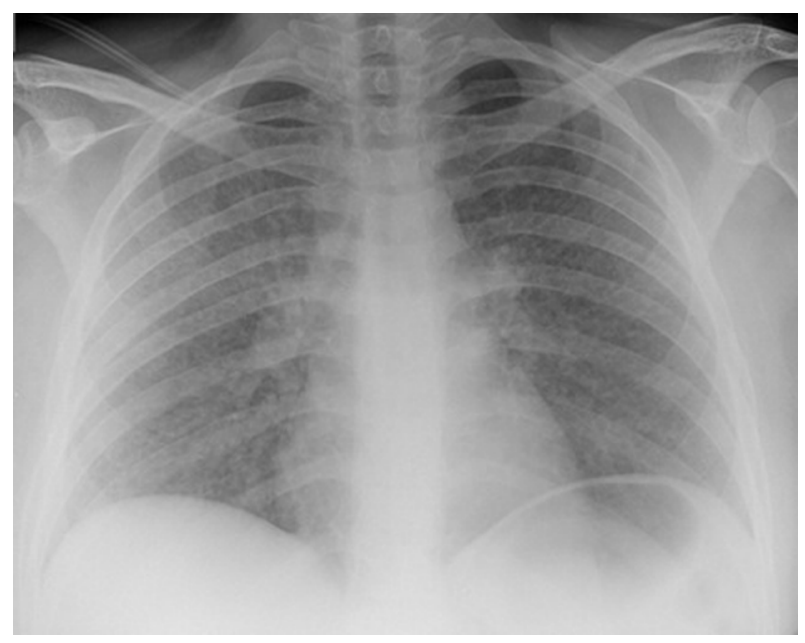

Figure 1 Extensive nodular shadowing on chest radiograph at presentation.

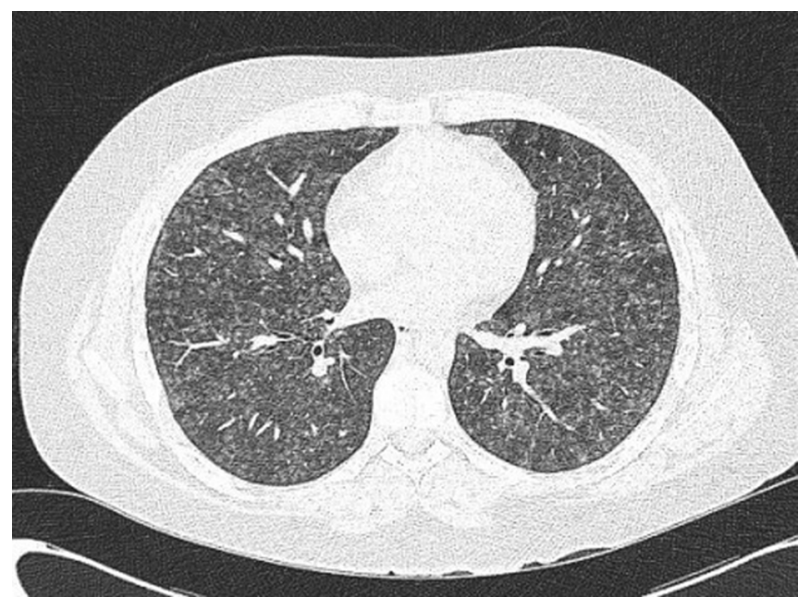

Figure 2 Thoracic high resolution CT scan demonstrating ground glass nodules in a predominantly centrilobular distribution suggestive of a radiological diagnosis of hypersensitivity pneumonitis. room air. A chest radiograph showed multiple nodules in a miliary pattern (figure 1). There was no evidence of consolidation. High resolution CT scan of thorax (figure 2) demonstrated extensive centrilobular ground glass opacities with no evidence of honeycombing. Serum avian precipitins (IgG antibodies) were significantly raised. There was no evidence of bacterial, viral or fungal infection on bronchoalveolar lavage fluid examination. Significant hypoxia precluded a trans-bronchial lung biopsy. The clinical and radiologic picture suggested the diagnosis of hypersensitivity pneumonitis (HP) secondary to avian exposure. Although chest radiograph may be normal in a majority of patients with $\mathrm{HP}^{1}$ and may rarely present as consolidation, ${ }^{2}$ this case suggests that miliary nodules on chest radiograph should raise the possibility of HP in appropriate clinical setting. The patient responded well to oral prednisone and withdrawal of exposure to antigen and a follow-up radiograph after 3 months showed significant resolution of the nodular change (figure 3 ). Differential diagnoses of miliary radiological pattern are protean and include miliary tuberculosis, primary or secondary pulmonary malignancy, sarcoidosis, pneumoconiosis or histoplasmosis. This case illustrates that HP should be considered in the differential diagnosis of miliary shadowing on chest radiograph.

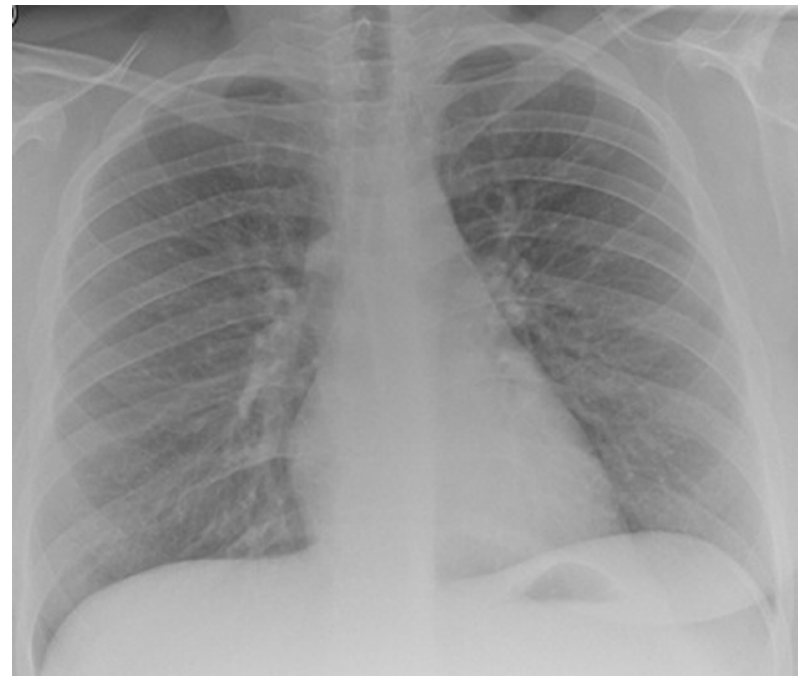

Figure 3 Follow-up chest radiograph following cessation of antigen exposure shows considerable resolution of nodular shadowing seen at presentation. 


\section{BMJ Case Reports}

Acknowledgements The authors thank Dr N Jagirdar for providing the radiological images for this case.

\section{Competing interests None.}

Patient consent Obtained.

\section{REFERENCES}

1. Unger GF, Scanlon GT, Fink JN, et al. A radiologic approach to hypersensitivity pneumonias. Radiol Clin North Am 1973;11:339-56.

2. Chassé $\mathbf{M}$, Blanchette $\mathrm{G}$, Malo J, et al. Farmer's lung presenting as respiratory failure and homogeneous consolidation. Chest 1986;90:783-4.

This pdf has been created automatically from the final edited text and images.

Copyright 2011 BMJ Publishing Group. All rights reserved. For permission to reuse any of this content visit http://group.bmj.com/group/rights-licensing/permissions.

BMJ Case Report Fellows may re-use this article for personal use and teaching without any further permission.

Please cite this article as follows (you will need to access the article online to obtain the date of publication).

Fahim A, Khan MN. An unusual cause of miliary radiographic pattern. BMJ Case Reports 2011;10.1136/bcr.10.2011.5060, Published XXX

Become a Fellow of BMJ Case Reports today and you can:

- Submit as many cases as you like

- Enjoy fast sympathetic peer review and rapid publication of accepted articles

- Access all the published articles

- Re-use any of the published material for personal use and teaching without further permission

For information on Institutional Fellowships contact consortiasales@bmjgroup.com

Visit casereports.bmj.com for more articles like this and to become a Fellow 